\title{
EXPERIMENTAL INVESTIGATION ON PITTING CORROSION RESISTANCE THROUGH NANO COATINGS
}

\author{
KALLEMPUDI VAHINI ${ }^{1}$, D. KESAVA ${ }^{2}$, N. RAMESH ${ }^{3}$, A. V. PRADEEP ${ }^{4} \&$ S. V. SATYA PRASAD ${ }^{5}$ \\ ${ }^{1,2,4,5}$ Assistant Professor, Department of Mechanical Engineering, Vignan's Institute of Engineering for Women, Visakhapatnam, \\ Andhra Pradesh, India \\ ${ }^{3}$ Assistant Professor, Department of Mechanical Engineering, Baba Institute of Technology and Sciences, Visakhapatnam, \\ Andhra Pradesh, India
}

\begin{abstract}
Based on the importance of nano particles and metal corrosion, the outstanding features of nano coatings on B-Graded mild steel samples are discussed in the present paper. Besides, in order to control the pitting corrosion and anti-fouling corrosion in case of marine equipment which would be corroded by sea atmosphere, salt water and snow in the sea environment. In this study, the changes in the epoxy based marine coatings was studied with the addition of $1 \%$ wt, $2 \%$ $w t, 4 \% w t$ and $6 \%$ wt of Aluminium(Al) nano powder whose particle size is $\sim 70 \mathrm{~nm}$. Corrosion performance was evaluated by applying these nano coatings on mild steel substrates of size $40 X 40 X 5 \mathrm{~mm}^{3}$ and by exposing them to salt water immersion test for a week. Results were observed as with an increasing concentration of Al nano powder, corrosion resistance was improved and mechanical properties as well.
\end{abstract}

KEYWORDS: Pitting Corrosion, Nano Coatings, Aluminium nano Powder and Salt Water Immersion Test

Received: Jun 06, 2020; Accepted: Jun 26, 2020; Published: Jul 30, 2020; Paper Id.: IJMPERDJUN2020542

\section{INTRODUCTION}

Due to the high strength, ability to work, less price and capability of reuse the metallic materials are treated with great importance in various fields such as manufacturing industries and construction [1-2]. There are such varieties of applications such as in household property, aerospace, automobile and marine components [3-4].Corrosion has become the major reason either to failure or harm for the application in engineering components, therefore corrosion is initiating for a severe threat to National assets [2].On the other hand, ship hull and equipment would be corroded by oceanic atmosphere, aquatic water, rain and snow in the sea atmosphere, because of the more salinity, the environment over the ocean contain large number of $\mathrm{Cl}^{-}$, high conductivity [5]. Among various types of corrosion problems, pitting corrosion damage is a major problem in several industrial applications and chemical productions due to impose of solid particles [6].All the industrial and marine equipment can be protected from the problem of corrosion through corrosion resistant materials, coating agents, Electro chemical protection and prevention of marine life fouling[7].Various practices proven that, coating protection with the application of nano materials is an effective anti-corrosion measure which works well either to prevent or delay the corrosion [8].By means of nano technology and the unique properties of nano particles, it was observed that, in the process of protection, than the conventional coatings powered nano materials are achieving better results [9]. Prabhu Ganesh et.al [10]conducted an experimentation with the silica coating on the modified surface zinc panel of the steel substrates. The samples were immersed in 5\% Sodium chloride solution was shown formation of red rust after 31 days. Meri-rong et.al [11] done investigation on treatment of passivation by means of sodium silicate solution and it was noticed that the 
morphology of silica coatings are dissimilar by AFM images, which is responsible for the resistant of the corrosion of silica coatings. C. N. Panagopoulos et. Al [12] have done their research on three layered coatings on the substrates of mild steel such as $\mathrm{Zn}$ as $1.8 \%$ Fe layer, a zinc phosphate layer and one, two or three alternative layers and it was observed corrosion resistance was increased.

\subsection{Pitting Corrosion}

This is a confined form of corrosion, results in production of cavities on the material surface as shown in fig (1) below. Among all types of corrosion, pitting corrosion is a more harmful corrosion. This is more damaging form of corrosion, because even a minor pit, with nominal overall loss of metaltends to a complete failure of the entire device. Protective oxide film will get chemical or mechanical damage due to the presence of pitting corrosion. This type of corrosion can also produce due to damage or uncaring application of a protective coating or even existence of non-equalities in the metallic structure of the element.

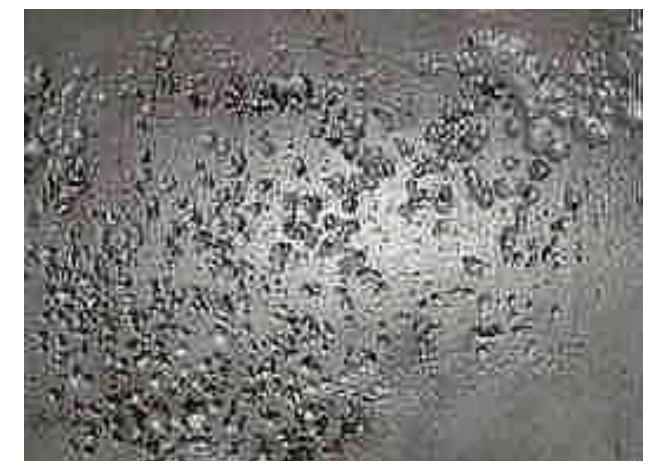

Figure 1: Formation of pitting corrosion

\section{METHOD OF CORROSION CONTROL}

The surface of metal can be protected from corrosion by following the processes such as placing a blockade between two metals, installing cathodic protection, through proper design of the structure, changing the environmental condition and protective coatings. Among all these methods, protective coatings play an important role in the prevention of corrosion by acting as a barrier between the metal surface and surroundings.

\subsection{Components of Coatings}

Most protective coatings are comprised of only three components

a. Binders (also known as"resins")

b. Pigments and

c. Solvents.

\section{NANO TECHNOLOGY IN COATINGS \& PAINTS}

Small is beautiful' is very well-known statement of long ago but now it has to be altered with 'small is not only beautiful butalso powerful'. It is an age of nanotechnology where the whole thing is going smaller and smaller to generategreat impression. Nanotechnology is one of the modern field which has ability to draw an attention from all over the world, and it has a capability to update most of the today's existing technology. Due to its excessive application in future, chemists, physicists, biologist andall other researchers from prominent fields are putting their heads together, and aiming what 
possibilities to be a new manufacturingrevolution. Nano-coatings are the materials which are produced by shrinking the material at the molecular level to form a denser product. The appearance and effectiveness of nanoparticles carries many advantages and prospects to paint and coating industry. The importance of nano technology was observed initially by the coating industry among all. By adding the nano particles, coatings can improve many properties of coating system and can produce multipurpose coatings with a little price difference. Such a coatings, sometimes made of self-assembling monolayers are applicable in many ways.

\subsection{Main Advantages of Nano-Coatings}

- Better surface presence.

- Better chemical resistance.

- Reduce in permeability to corrosive atmospheretherefore better corrosion properties.

- Optical clearness.

- Improvement in modulus and thermal stability.

- Easy to clean surface.

\section{EXPERIMENTAL PROCEDURE}

\subsection{Selection of Materials}

As mild steel of Grade-A has a good resistance to corrosion, we have chosen mild steel of Grade-B in order to have a good research experience in our experimentation of pitting corrosion resistance.

Mild steel has the following properties

- It is a very strong metal due to the presence of low carbon.

- It has a good resistance to breakage.

- As opposed to higher carbon steels, it is quite malleable, even when cold.

\subsection{Pretreatment Process}

Prior to the application of any coating, the surface must be suitably prepared to receive the coating material. Good surface preparation is maybe the most important part of the entire coating job. In this regards, mild steel samples are exposed to the process of Abrasive Grit Blasting. Grit blasting is a process in which the surface in question is impacted at high velocity by hard angular particles to such extent that unnecessary material on the surface is removed, and a clean active metal surface was exposed.After the process of Grit blasting within the duration of one hour the mild steel samples were exposed to Zinc Silicate coat of 75 microns by using spray gun.The purpose of Zinc Silicate coat is to avoid the corrosion before the application of protective coatings to the particular metal surface as it can protect the metal for maximum one day.

\subsection{Procurement of Nano Powders}

The aim of nanotechnology is the capability to producenano-sized particles, for example nanopowders are solid particles which can quantify on the scale of nano, typically comprised of four to five grainsaltogether.By means of high purity aluminumas a raw material and due to its minor grain size, it can be produced in higher quantities at less price. In the 
present study Aluminiumnano particles are considered due to the nature of highly effective catalysts.

\subsection{Selection of Coatings}

SIGMA COVER 280 (PRIMARY)

Universal epoxy anti corrosive primer, based upon pure epoxy technology.

SIGMADUR 550 (SECONDARY COATING)

Two-component, alphatic acrylic polyurethane finish.

\section{EXPERIMENTATION}

\section{STEP1}

- Six B-Graded mild steel Specimens of size each 40X40X5mm3have been selected.

- Grit blasting is done on the mild steel plates in order to remove the rust and other dust particles.

- After the process of grit blasting, within one hour, Zinc Silicate coat of 75 microns thickness was applied by using spraying gun.

\section{STEP 2}

- Primer (Sigma Cover 280) was applied on the samples, of thickness 50 microns in order to prevent the specimensfrom moisturewhich is present in the atmosphere.

- The samples were left undisturbed for seven days to dry.

- First plate has been left with Primer Coat and the Remaining plates were coated with top coat as follows.

\section{STEP 3}

- The top coat which was a dual pack of Sigma Dur 550, of thickness 75 micros was applied on the Samplesby injecting aluminium nano powder in various proportions such as $1 \% \mathrm{wt}, 2 \% \mathrm{wt}, 4 \% \mathrm{wt}, 6 \% \mathrm{wt}$ to the coating.

- For the Second sample top coat was applied without injecting nanoparticles.

- For the third sample we injected $1 \mathrm{wt} \%$ of aluminium nano powder into the top coat and applied it by using spray gun.

- Similarly, $2 \% \mathrm{wt}, 4 \% \mathrm{wt}, 6 \% \mathrm{wt}$ of Aluminium nano powder was injected into the top coat and applied to the fourth, fifth and sixth samples respectively.

- The Samples were then left undisturbed for few days until they were dried completely.

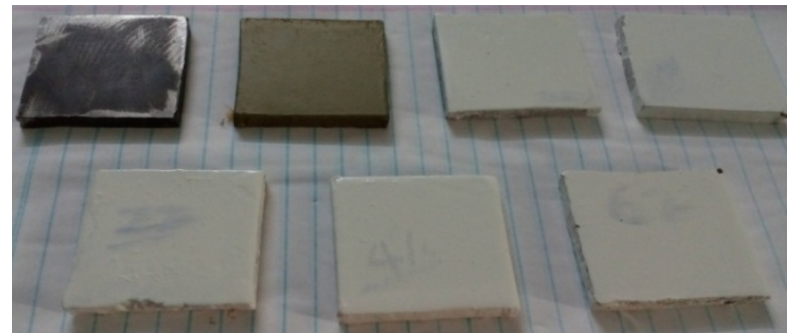

Figure 2: Six coated samples of B-Graded mild steel 
The above fig (2) shows the samples of mild steel with primer coat, top coat without injecting Al nano particles, $1 \% \mathrm{wt}, 2 \% \mathrm{wt}, 4 \% \mathrm{wt}$ and $6 \% \mathrm{wt}$ of $\mathrm{Al}$ nano powder respectively.

\section{STEP4}

Different tests such asHardness Test, Dry Film Thickness Test, Surface Roughness Test and Corrosion Test (Salt Water Immersion Test)were carried out on the test specimens inorderto check various mechanical properties and corrosion resistance of the Samples.

\section{CORROSION TESTING THROUGH WEIGHTLOSS METHOD (SALT WATER IMMERSION TEST)}

Mild Steelis the most frequently used metal becauseof its conductivity, strength, obstacle properties and abundantquality. For mild Steelthe resistance of corrosion depends on the defending oxide film, which is steady when the pH is in the middle of 4.5 and 8.5 below and above the $\mathrm{pH}$ it starts corrosion. In the present study,HCL is used as a medium. HCL solutions are used for pickling, chemical and electrochemical etching.

The experiment was performed with mild steelsamples which were cleaned and etched well. Accurate weight of the metal samples was measuredby using digital balance. Each of $150 \mathrm{ml}$ capacity of 5 molar HCL solution mixed with distilled water was introduced into six reaction vessels. The specimens were dipped in the chemical solution and left undisturbed for a time period of $24 \mathrm{hrs}$. After $24 \mathrm{hrs}$, the specimens were taken out from the solution and wiped with a tissue paper and again the weights of the all six specimenswere measured by using digital balance. This process wasrepeated for five more times at an interval of 24 hrseach and the respected weights were noted down. These values helpin observing the weight reduction of the specimens which indicates the level of formation of corrosion on the specimens. The following fig (3) to fig (8) indicates the changes observed in the six samples during six different days.

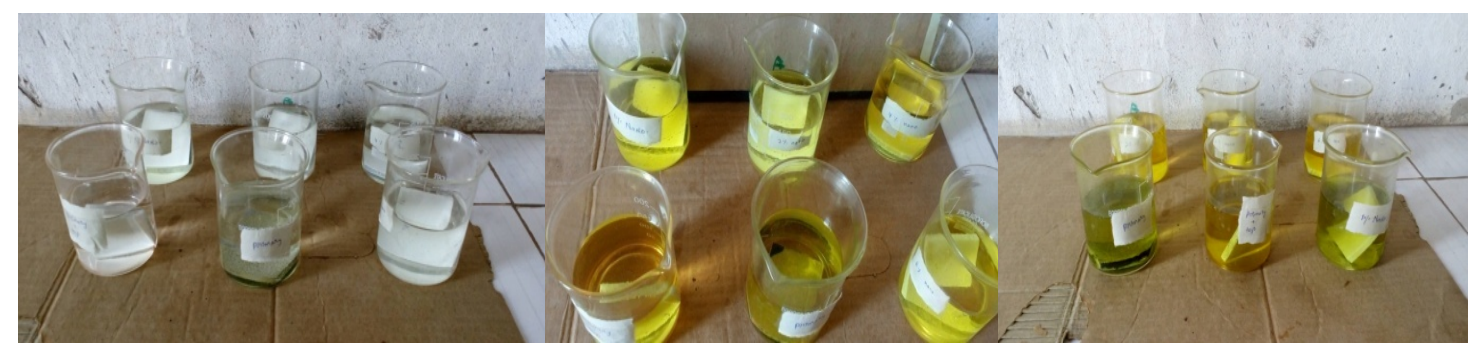

Figure 3: Observationon Day-1 Figure 4: Observation on Day-2 Figure 5: Observationon Day -3

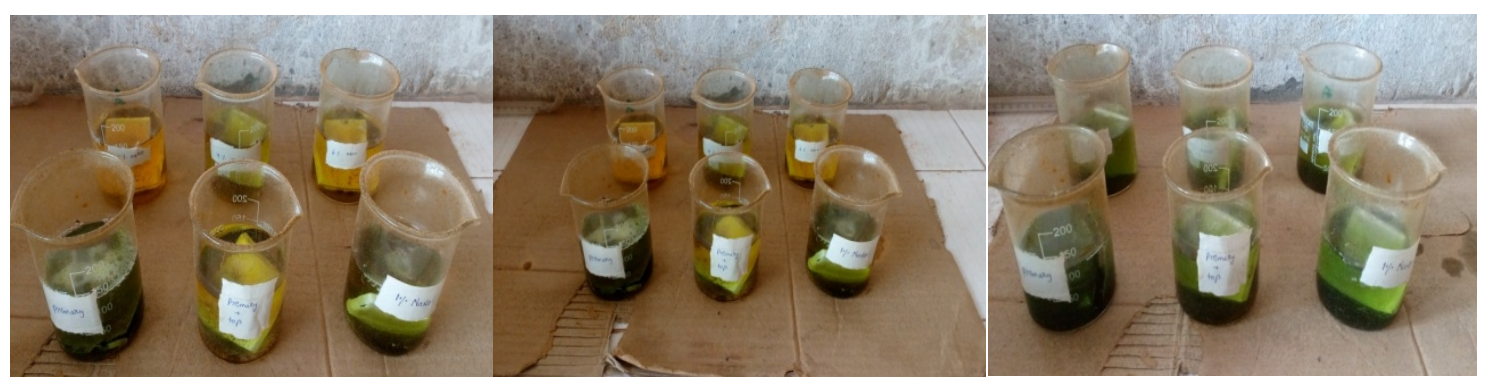

Figure 6: Observation on Day-4 Figure 7: Observation on Day-5 Figure 8: Observation on Day- 6

Fig. 3 to 8:Immersion of mild steel samples (with primer coat, top coat without injecting Al nano particles, 1\% wt, $2 \% \mathrm{wt}, 4 \% \mathrm{wt}, 6 \% \mathrm{wt}$ of $\mathrm{Al}$ nano powder respectively) in a 5 molar HCL solution.

From the above figures 3 to 8 , we observe the level of corrosionin the mild steel samples day by day by the 
chemical reaction of HCL solution and distilled water in which they were immersed.

The metal sample doesn't undergo any type of corrosion immediately as they were immersed in the chemical solution. As shown in the Fig (4), on the second day we observe a minute variation in the weights of each metal sample weighed on the digital balance due to the initiation of chemical reaction by the HCL solution.

From fig (5) it was observed that on the third dayeach metal sample starts corroding which can be observed through the weight loss percentages.As the time period of contact between the metal specimens and HCL solution increases, the corrosion level also increases simultaneously according to the results shown in the Table 1 below.

Table 1: Day by day observation in weight loss of mild steel samples

\begin{tabular}{|c|c|c|c|c|c|c|c|c|c|}
\hline \multirow[b]{2}{*}{$\begin{array}{l}\mathbf{S} \\
\mathbf{N} \\
\mathbf{0}\end{array}$} & \multirow[b]{2}{*}{$\begin{array}{c}\text { Sample } \\
\text { s }\end{array}$} & \multirow[b]{2}{*}{ Specimen } & \multirow{2}{*}{$\begin{array}{c}\text { Original } \\
\text { Weight } \\
\text { of Each } \\
\text { Sample } \\
\text { (Grams) }\end{array}$} & \multicolumn{6}{|c|}{ Reduction of Weight (\%) } \\
\hline & & & & $\begin{array}{l}\text { Day } 1 \\
\text { Obser } \\
\text { vation }\end{array}$ & $\begin{array}{c}\text { Day } 2 \\
\text { Observa } \\
\text { tion }\end{array}$ & $\begin{array}{c}\text { Day } 3 \\
\text { Observa } \\
\text { tion }\end{array}$ & $\begin{array}{c}\text { Day } 4 \\
\text { Observat } \\
\text { ion }\end{array}$ & $\begin{array}{c}\text { Day } 5 \\
\text { Observ } \\
\text { ation }\end{array}$ & $\begin{array}{c}\text { Day } 6 \\
\text { Observ } \\
\text { ation }\end{array}$ \\
\hline 1 & $\begin{array}{l}\text { Sample } \\
1\end{array}$ & $\begin{array}{l}\text { Primer Coat } \\
\text { Sample }\end{array}$ & 90 & 1 & 2.23 & 4.5 & 6.67 & 8.89 & 13.4 \\
\hline 2 & $\begin{array}{l}\text { Sample } \\
2\end{array}$ & $\begin{array}{l}\text { Top Coat } \\
\text { (Without Al } \\
\text { Nano Particles) } \\
\end{array}$ & 90 & 0 & 0 & 2.13 & 4.4 & 7.7 & 10.87 \\
\hline 3 & $\begin{array}{l}\text { Sample } \\
3\end{array}$ & $\begin{array}{l}\text { Sigmadur } 550+ \\
1 \% \\
\text { Wtaluminiumna } \\
\text { no Powder }\end{array}$ & 90 & 0 & 0 & 2.23 & 4.5 & 6.67 & 8.89 \\
\hline 4 & $\begin{array}{l}\text { Sample } \\
4\end{array}$ & $\begin{array}{l}\text { Sigmadur } 550+ \\
2 \% \\
\text { Wtaluminiumna } \\
\text { no Powder }\end{array}$ & 90 & 0 & 0 & 0 & 2.2 & 4.3 & 8.6 \\
\hline 5 & $\begin{array}{l}\text { Sample } \\
5\end{array}$ & $\begin{array}{l}\text { Sigmadur } 550+ \\
4 \% \\
\text { Wtaluminiumna } \\
\text { no Powder }\end{array}$ & 90 & 0 & 0 & 0 & 1.09 & 2.2 & 6.53 \\
\hline 6 & $\begin{array}{l}\text { Sample } \\
6\end{array}$ & $\begin{array}{l}\text { Sigmadur } 550+ \\
6 \% \\
\text { Wtaluminiumna } \\
\text { no Powder }\end{array}$ & 90 & 0 & 0 & 0 & 0 & 1.12 & 2.3 \\
\hline
\end{tabular}

\section{OBSERVATIONS \& RESULTS}

\subsection{Mechanical Properties}

Table 2: Hardness test using Rockwell Hardness Testing Machine

\begin{tabular}{|c|l|l|c|c|c|}
\hline S.No & \multicolumn{1}{|c|}{ Specimen } & Indentation & $\begin{array}{c}\text { Load } \\
\text { (Kgf) }\end{array}$ & $\begin{array}{c}\text { Rockwell } \\
\text { Hardness } \\
(\mathbf{R})\end{array}$ & Result \\
\hline 1 & Primer Coat Sample & Diamond & 150 & C61-C97 & 36 \\
\hline 2 & Top Coat (Without Al Nano Particles) & Diamond & 150 & C81-C19 & 38 \\
\hline 3 & $\begin{array}{l}\text { SIGMADUR 550 + } \\
1 \% \text { wtAluminiumnano powder }\end{array}$ & Diamond & 150 & C80-C21 & 40 \\
\hline 4 & $\begin{array}{l}\text { SIGMADUR 550 + } \\
2 \% \text { wtAluminiumnano powder }\end{array}$ & Diamond & 150 & C76-C18 & 40 \\
\hline 5 & $\begin{array}{l}\text { SIGMADUR 550 + } \\
4 \% \text { wtAluminiumnano powder }\end{array}$ & Diamond & 150 & C58-C99 & 41 \\
\hline 6 & $\begin{array}{l}\text { SIGMADUR 550 + } \\
6 \% \text { wtAluminiumnano powder }\end{array}$ & Diamond & 150 & C38-C79 & 41 \\
\hline
\end{tabular}


Table 3: SurfaceRoughness,Dry Film Thickness,Dry Time \& Agglomeration tests of all six mild steel samples

\begin{tabular}{|c|c|c|c|c|c|}
\hline S.No & Specimen & $\begin{array}{c}\text { Surface } \\
\text { Roughness } \\
\text { ( Ra) } \mu \mathrm{m} \\
\end{array}$ & $\begin{array}{c}\text { Film } \\
\text { Thickness } \\
(\mu \mathrm{m})\end{array}$ & $\begin{array}{l}\text { Dry Time } \\
\text { (Hrs) }\end{array}$ & $\begin{array}{l}\text { Agglomeration Of } \\
\text { Nano Particles }\end{array}$ \\
\hline 1 & $\begin{array}{l}\text { Primer Coat } \\
\text { Sample }\end{array}$ & $\begin{array}{c}0.907 \\
(\text { Good })\end{array}$ & 104.28 & More( 24) & ---------------- \\
\hline 2 & $\begin{array}{l}\text { Top Coat } \\
\text { (Without Al Nano } \\
\text { Particles) }\end{array}$ & $\begin{array}{l}0.858 \\
\text { (Good) }\end{array}$ & 146.28 & More( 24) & ----------------- \\
\hline 3 & $\begin{array}{l}\text { SIGMADUR } 550 \\
+ \\
1 \% \\
\text { wtAluminiumnano } \\
\text { powder }\end{array}$ & $\begin{array}{c}0.430 \\
\text { (Good) }\end{array}$ & 155.71 & $\operatorname{Less}(\sim 24)$ & Low \\
\hline 4 & $\begin{array}{l}\text { SIGMADUR } 550 \\
+ \\
2 \% \\
\text { wtAluminiumnano } \\
\text { powder }\end{array}$ & $\begin{array}{c}0.331 \\
(\text { High })\end{array}$ & 161.78 & $\operatorname{Less}(\sim 24)$ & Low \\
\hline 5 & $\begin{array}{l}\text { SIGMADUR } 550 \\
+ \\
4 \% \\
\text { wtAluminiumnano } \\
\text { powder }\end{array}$ & $\begin{array}{c}0.339 \\
(\text { High })\end{array}$ & 162.9 & $\operatorname{Less}(\sim 12)$ & High \\
\hline 6 & $\begin{array}{l}\text { SIGMADUR } 550 \\
+ \\
6 \% \\
\text { wtAluminiumnano } \\
\text { powder }\end{array}$ & $\begin{array}{c}0.109 \\
\text { (High) }\end{array}$ & 162 & Very Less $(\sim 12)$ & Very High \\
\hline
\end{tabular}

\subsection{Corrosion Testing Graphs}

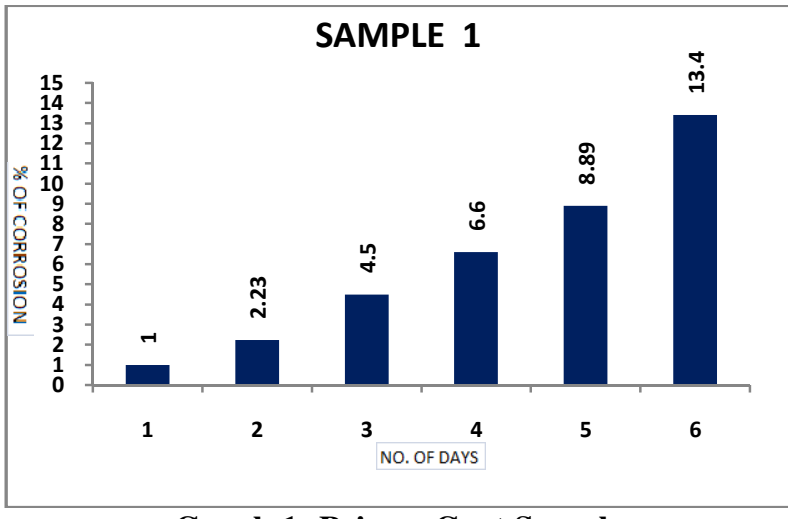

Graph 1: Primer Coat Sample

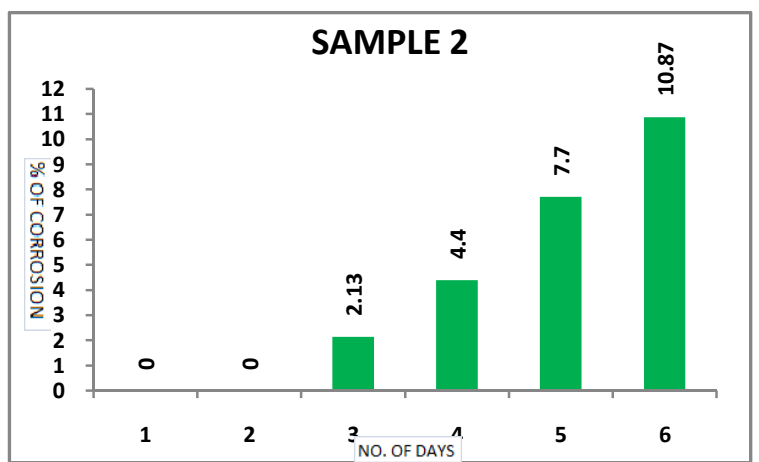

Graph 2: Top coat sample (Without Al nanoparticles) 


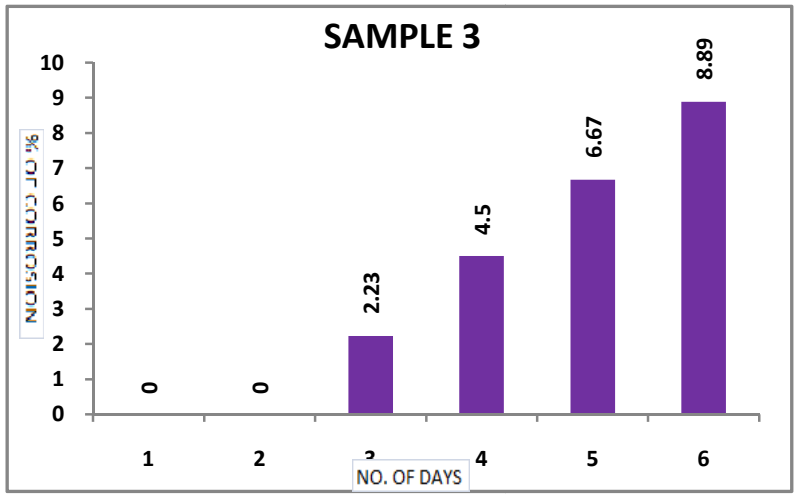

Graph 3: SIGMADUR 550 + $1 \%$ wtAluminium nano powder

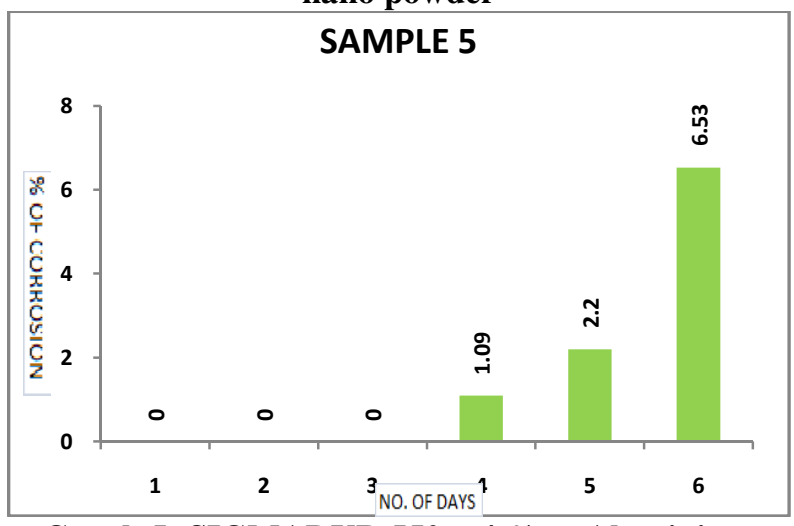

Graph 5: SIGMADUR 550 + $4 \%$ wtAluminium nano powder

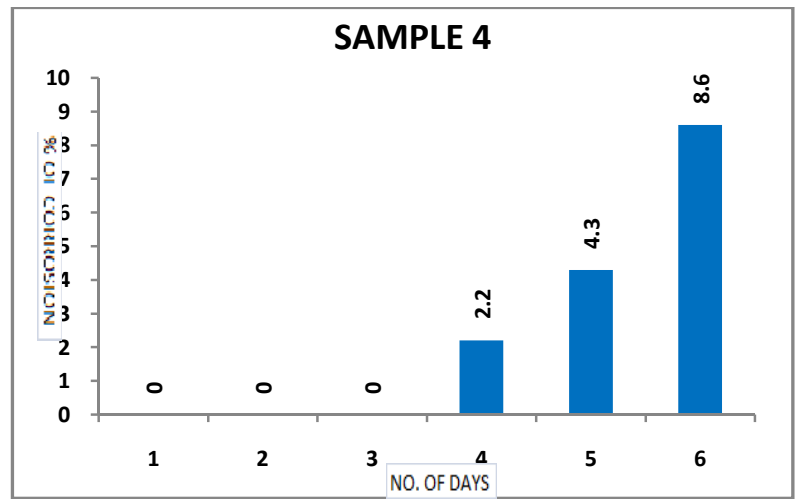

Graph 4:SIGMADUR $550+2 \%$ wtAluminium nano powder

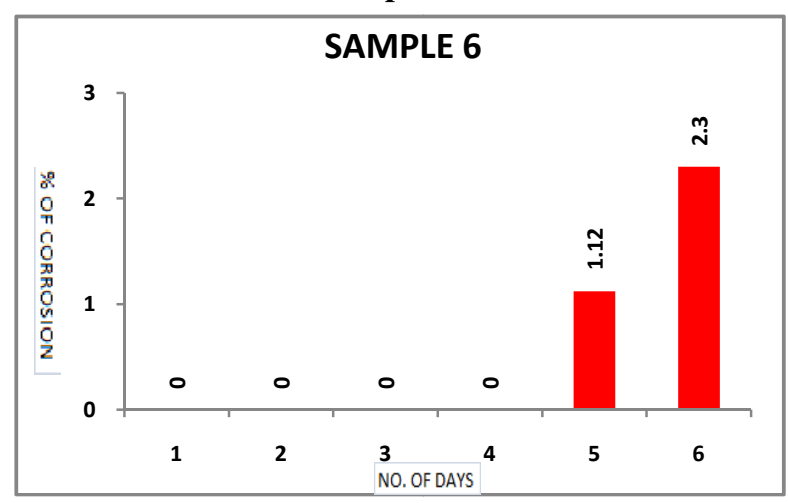

Graph 6: SIGMADUR 550 + $6 \%$ wtAluminium nano powder

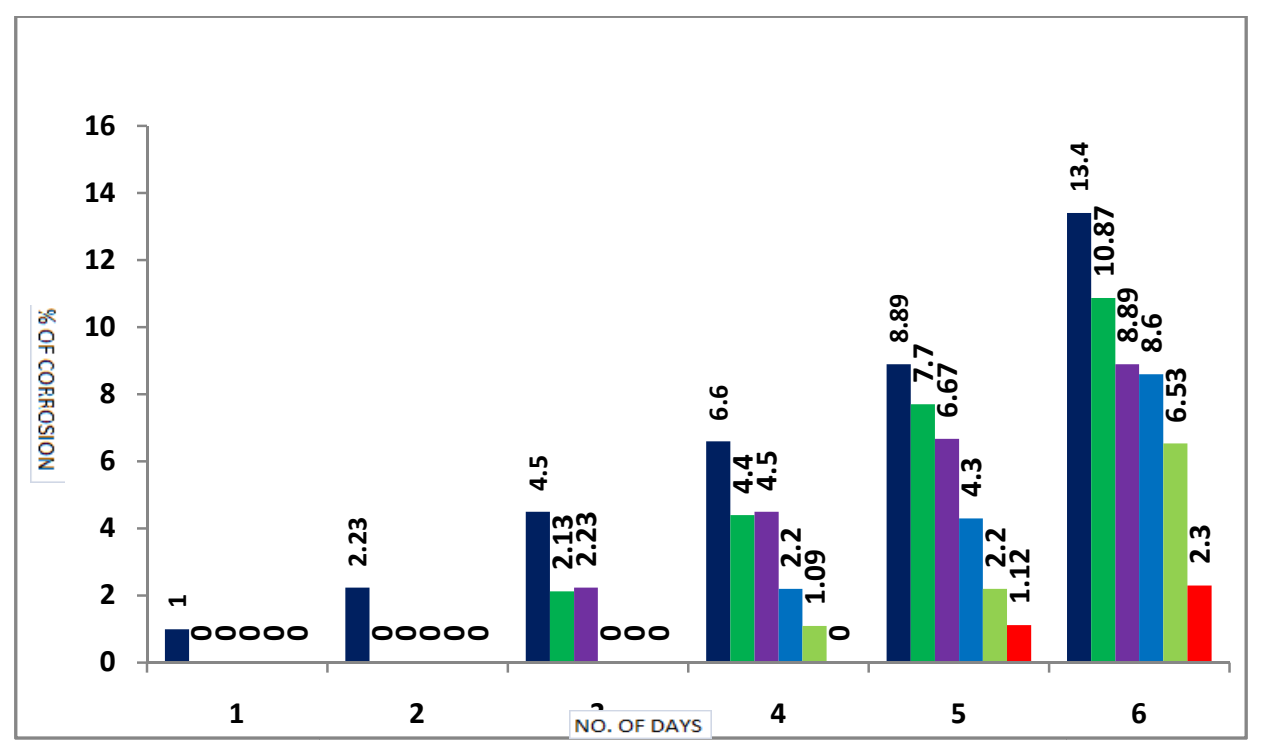

Graph 7: Comparison among all mild steel specimens observed for six days

\section{CONCLUSIONS}

The rate of corrosion and the efficiency for mild steel specimens which are coated with protective coatings with the combination of nano particles such as Aluminium nano powder in different proportions enhance the corrosion protection efficiency which was observed by immersing the mild steel samples in each of $150 \mathrm{ml}$ capacity of 5 molar HCL solution 
mixed with distilled water.This was performed by adopting the technique of "weight loss method".

In this method we observe that the inhibition efficiency increases with the increase in the percentage of concentration of nanoparticles along with layers of protective coatings on the mild steel specimens.

The results obtained from the weight reduction of each metal sample, day by day indicates the percentage of corrosion that has been underwent.By the obtained results and graphs, after performing the weight loss method it was found that the specimen which has higher concentration of nano particle i.e, the metal sample coated with the composition of primer coat, top coat with $6 \%$ of $\mathrm{Al}$ nano particles injected in it acts as a good corrosion inhibitor when compared to remaining samples which have a lesser concentration of nano particles.

Also it's been observed that, the mechanical properties such as hardness, surface roughness, film thickness, dry time has also been improvised with the addition of nano particles.

\section{REFERENCES}

1. F. Zhang, M. Reich, O. Kessler and E. Burkel, "The potential of rapid cooling spark plasma sintering for metallic materials" Mater. Today, 2013, 16, PP 192-197.

2. L. Winkless, Mater. Today, 2015, 18, 245.

3. F. Presuel-Moreno, M. A. Jakab, N. Tailleart, M. Goldman and J. R. Scully. "Corrosion-resistant metallic coatings"Mater. Today, 2008, 11, PP 14-23.

4. Saber, D., KhAbd El-Aziz, and A. Fathy."Corrosion behavior of copper-alumina nanocomposites in different corrosive media." Int. J. Mech. Eng 5 (2016): 1-10.

5. C. Stromberg, P. Thissen, I. Klueppel, N. Fink and G. Grundmeier, "Synthesis and characterisation of surface gradient thin conversion films on zinc coated steel" Electrochim. Acta, 2006, 52, PP 804-815.

6. Yanlan Jiang, Xiaorui Liang, Shiyong Wu. "Nanotechnology applications in the field of ship protection" Materials Science Forum Vol. 694 (2011) pp 239-243.

1. EL-SHENNAWY, M., and ADEL A. OMAR. "MANUFACTURING OF NANO/MICRO COMPOSITES USING FRICTION STIR PROCESSING."International Journal of Mechanical Engineering (IJME) 4. 3, Apr - May 2015, 29-48

7. E. Mahdi, A. Rauf, E.O. Eltai. "Effect of temperature and erosion on pitting corrosion of X100 steelin aqueous silica slurries containing bicarbonate and chloride content" Elsevier, Corrosion Science 83 (2014) pp48-58.

8. Phuong Nguyen-Tri, Tuan Anh Nguyen, Pascal CarriereandCuong Ngo Xuan. "Nanocomposite Coatings: Preparation, Characterization,Properties, and Applications" HindawiInternational Journal of Corrosion Volume 2018, Article ID 4749501, 19 pages.

2. Nithyanandam, K., and T. Palanisamy."Wettability analysis on copper substrate by emery abrasion and copper nano coating." Int. J. Mech. Prod. Eng. Res. Dev 8 (2018): 583-590.

9. R. Joseph Rathish, R. Dorothy, R. M. Joany, M. PandiarajanandSusaiRajendran. "Corrosion Resistance Of Nanoparticle Incorporated Nano Coatings" Eur. Chem. Bull., 2013, 2(12), 965-970.

10. J. N. Hansidawani, H. N. Azlina, H. Norita, N. Samat, H. N. Bonnia and S. N. Surip. "ZnO Nanoparticles for Anti-corrosion nanaocoatings of carbon steel” Materials Science Forum, ISSN: 1662-9752, Vol. 894, pp 76-80.

3. Muralishwara, K., et al. "Sliding wear resistance and microhardness of epoxy clay Nanocomposite coatings." International 
Journal of Mechanical and Production Engineering Research and Development (IJMPERD 9.5 (2019): 919-930.

11. PrabhuGanesan, Yoon-Seok Choi, Swaminatha P. Kumaragu and Branko N. Popov. "Development of Corrosion Resistant Silica Coating on Surface Modified Zinc Coated Steel”2006 SUR/FIN Proceedings.

12. Mei-rong Yuan, Jin-tang Lu, Gang Kong. "Effect of SiO2:Na2O molar ratio of sodium silicate on the corrosion resistance of silicate conversion coatings" Elsevier, 204 (2010) pp 1229-1235.

13. C. N. Panagopoulos, E. P. Georgiou, M. G. Tsoutsouva, M. Krompa. "Composite multilayered coatings on mild steel” J. Coat. Technol. Res. (2011), 8 (1) PP 125-133.

\section{AUTHOR'S PROFILE}

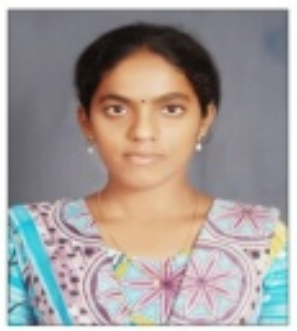

Mrs. K.Vahini, received her bachelor degree in mechanical engineering from JNTUniversity, Kakinada and master degree in marine engineering from IMU,Visakhapatnam. Present she is working as Assistant Professor in the department of mechanical engineering, VIEW, Visakhapatnam, Andhra Pradesh, India. She has an experience of 7 years as an academician. She is also a research scholar from Andhra University, working on alternative fuels to diesel engines. Her area of specialization is dealing with I.C engines and machine design.

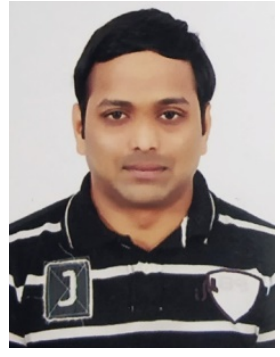

Mr. D.Kesava, received his bachelor degree in Mechanical Engineering from JNTUniversity, Kakinada and Master's degree inHeat Transfer in Energy System from Andhra University, Visakhapatnam. Present he is working as Assistant Professorin Department of Mechanical Engineering, VIEW, Visakhapatnam, Andhra Pradesh, India. He has an experience of 4 years as an academician. His area of specialization is dealing with I.C Engines and Thermal Energy Storage Systems.

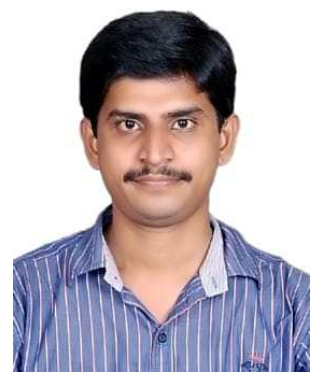

Mr. N. Ramesh, received his bachelor degree in Production Engineering from Acharya NagarjunaUniversity, Guntur and master degree in CAD/CAM from JNTUniversity, Kakinada. Present he is working as Assistant Professor in the department of Mechanical Engineering, BITS, Visakhapatnam, Andhra Pradesh, India. He has an experience of 8 years as an academician. He is also a research scholar from Andhra University, working on Alternative Fuels to diesel engines. His area of specialization is dealing with I.C engines and Manufacturing. 


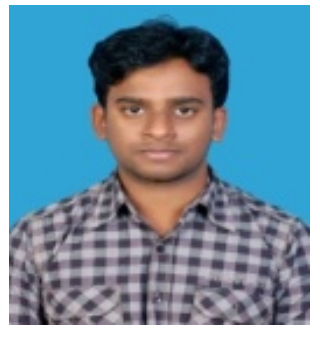

Mr. A.V.Pradeep, received his B.EngM.Eng in Mechanical Engineering from JNTU Kakinada. He is currentlyAssistant Professorin the department of Mechanical Engineering in VIEW, Visakhapatnam, AndhraPradesh, India. He has an experience of 8 years as academician. $\mathrm{He}$ is also a reesrch scholar from JNTUK. His area of expertise in manufacturing and metal cutting. He has authored many research articles and conference papers for many repeated journals.

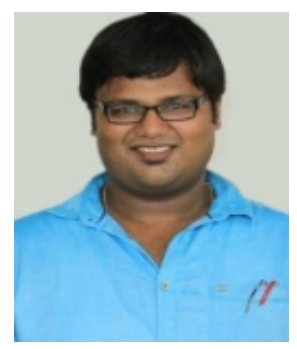

Mr.S.V.Satya Prasad, received received his B.EngM.Eng in mechanical engineering from JNTU Kakinada. He is currentlyAssistant Professorin the department of Mechanical Engineering in VIEW, Visakhapatnam, AndhraPradesh, India. He has an experience of 08 years as academician. $\mathrm{He}$ is also a research scholar from JNTUK. His area of expertise in material science. He has authored many research articles and conference papers for many repeated journals. 

